\title{
Seismotectonic study of the Fergana Region (Southern Kyrgyzstan): distribution and kinematics of local seismicity
}

\author{
Christian Feld ${ }^{1 *}$, Christian Haberland ${ }^{1}$, Bernd Schurr ${ }^{1}$, Christian Sippl ${ }^{1,2}$, Hans-Ulrich Wetzel $^{1}$, Sigrid Roessner ${ }^{1}$, \\ Michèle Ickrath', Ulan Abdybachaev ${ }^{3}$ and Sagynbek Orunbaev ${ }^{3}$
}

\begin{abstract}
We present new seismicity and focal-mechanism data for the Fergana basin and surrounding mountain belts in western Kyrgyzstan from a temporary local seismic network. A total of 210 crustal earthquakes with hypocentral depths shallower than $25 \mathrm{~km}$ were observed during a 12-month period in 2009/2010. The hypocenter distribution indicates a complex net of seismically active structures. The seismicity derived in this study is mainly concentrated at the edges of the Fergana basin, whereas the observed rate of seismicity within the basin is low. The seismicity at the dominant tectonic feature of the region, the Talas-Fergana fault, is likewise low, so the fault seems to be inactive or locked. To estimate the uncertainties of earthquake locations derived in this study, a strong explosion with known origin time and location is used as a ground truth calibration event which suggests a horizontal and vertical accuracy of about $1 \mathrm{~km}$ for our relocations. We derived 35 focal mechanisms using first motion polarities and retrieved a set of nine moment tensor solutions for earthquakes with moment magnitude (Mw) ranging from 3.3 to 4.9 by waveform inversion. The solutions reveal both thrust and strike-slip mechanisms compatible with a NW-SE direction of compression for the Fergana region. Two previously unknown tectonic structures in the Fergana region could be identified, both featuring strike-slip kinematics. The combined analysis of the results derived in this study allowed a detailed insight into the currently active tectonic structures and their kinematics where little information had previously been available.
\end{abstract}

Keywords: Seismotectonics; Seismicity; Moment tensor inversion; Neotectonics; Focal mechanisms; Fergana basin; Tien Shan

\section{Findings}

\section{Introduction}

The active tectonics in Central Asia is dominated by the convergence of the Indian and Eurasian continental plates. Despite being situated far behind from the deformation front, two of the earth's largest mountain belts, the Pamirs and Tien Shan (Shan = Mountains), have rapidly risen due to this convergence (Molnar and Tapponnier 1975; Burtman 2000; Windley et al. 1990; Burtman 1975; Yin et al. 1998; Ducea et al. 2003). The Tien Shan are a prototype of an active intracontinental mountain belt, characterized by separate ranges with intermontane basins

\footnotetext{
* Correspondence: cfeld@gfz-potsdam.de

'Helmholtz-Zentrum Potsdam - Deutsches GeoForschungsZentrum GFZ,

Telegrafenberg, 14473 Potsdam, Germany

Full list of author information is available at the end of the article
}

between them, bounded by reverse faults either on one side (e.g., Chu basin and west Alai basin) or on both sides (e.g., Issyk-Kul basin, Naryn basin and Fergana basin; Cobbold et al. 1996). In active intracontinental belts, deformation is distributed and several faults are usually concurrently active (Zubovich et al. 2010). The Fergana basin (Figure 1), an east-west-trending intermontane basin, and the surrounding mountain belts as part of the southwestern Tien Shan are also affected by intracontinental deformation. This ongoing tectonic activity in combination with pronounced topographic relief also leads to high landslide activity which is especially concentrated in the weakly consolidated meso- and Cenozoic sediments along the eastern rim of the Fergana basin and frequently causes damages to settlements and infrastructure as well as loss of lives (Haberland et al. 2011; Roessner et al. 2005).

\section{实}

(C) 2015 Feld et al.; licensee Springer. This is an Open Access article distributed under the terms of the Creative Commons Attribution License (http://creativecommons.org/licenses/by/4.0), which permits unrestricted use, distribution, and reproduction in any medium, provided the original work is properly credited. 


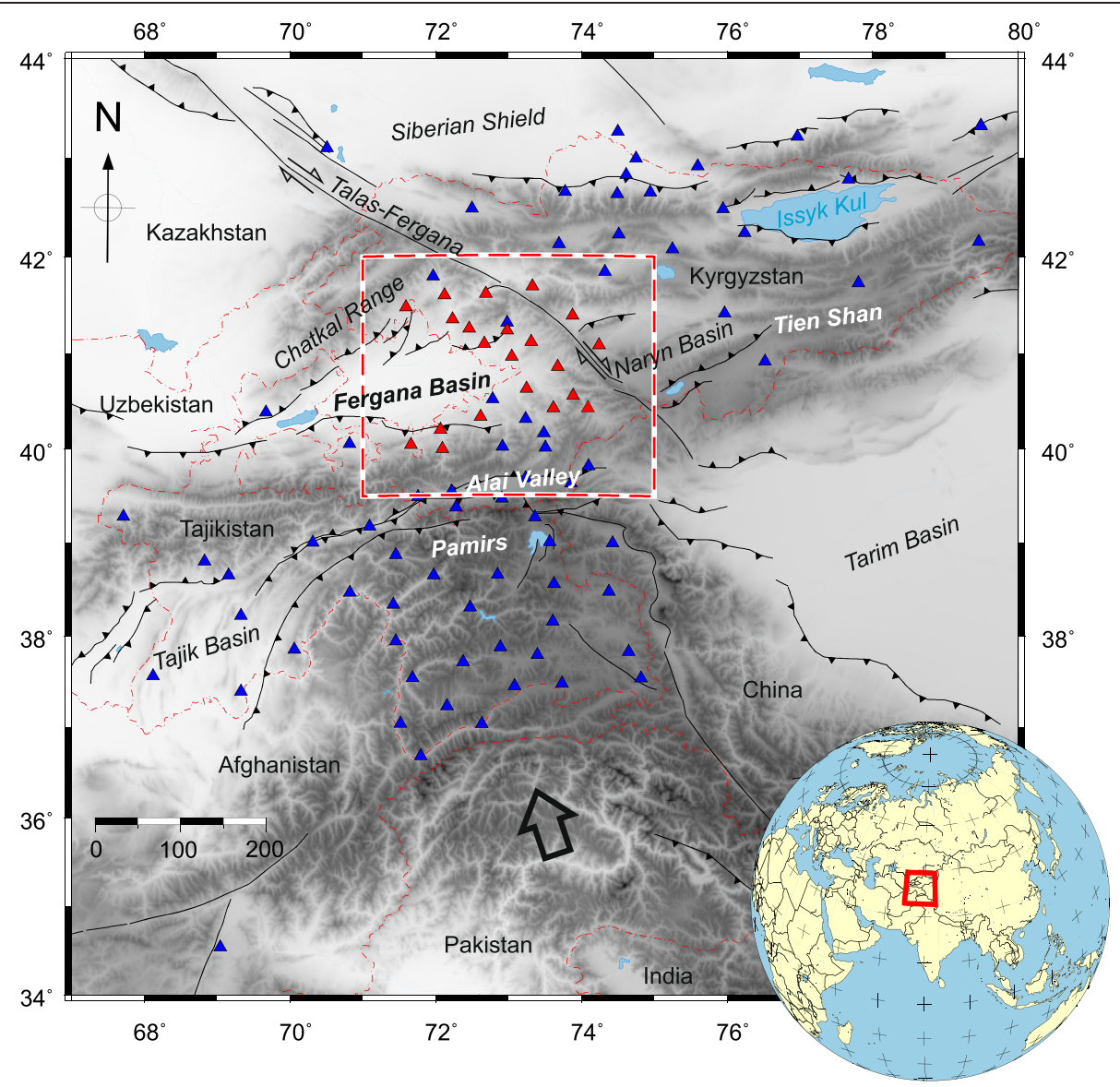

Figure 1 Map of Central Asia. The map shows location of the study area (red dashed box), the Fergana Basin and surrounding mountain belts, main tectonic features from Styron et al. 2010 and Taylor and Yin 2009, Red triangles show stations from the FERGANA network, blue triangles are stations from additional networks (e.g., TIPAGE, KNET,...), and black arrow indicates direction of movement of the Indian plate.

Four historic events of $M>7$, which have occurred since 1900, and a recent significant earthquake on 19 July 2011 with $\mathrm{MW}=6.1$ at the southern rim of the Fergana basin show that the Fergana region is also capable of large magnitude earthquakes, posing a high seismic hazard to this region (peak ground acceleration above $4.8 \mathrm{~m} / \mathrm{s}^{2}$ USGS). Due to the 2011 earthquake, at least 13 people were killed, 86 people injured, and several buildings destroyed in the city of Fergana, the capital of the Fergana Province, Uzbekistan (USGS). The earthquake featured reverse slip, most likely on a southdipping thrust fault between the Pamir Mountains to the south and the Fergana basin to the north (USGS). Beside the seismicity in the Fergana region derived from global networks, some regional investigations (Ni 1978; Ghose et al. 1998) provide fault plane solutions which show predominantly thrust-faulting mechanisms. However, the currently active tectonic structures of the Fergana region are poorly known because of the lack of local seismic studies in this region.
This study presents new seismicity data from a local seismic network including hypocenter locations as well as fault plane solutions from first motion data and waveform inversion. To gain better insights into the regional neotectonic framework, the distribution and kinematics of the local seismicity was analyzed, complementing the results of teleseismic investigations of the region. The low detection threshold of the local seismic network and the increased accuracy due to the relatively small interstation distance of about $50 \mathrm{~km}$ (compared to permanent regional networks) yield an image of active tectonic structures with kilometer-scale resolution.

\section{Structural setting and previous data Tectonic setting}

The Fergana basin is an east-west-trending intermontane basin filled with up to $8 \mathrm{~km}$ of Cenozoic sediments situated in the southwestern part of the Tien Shan (Bazhenov 1993; Thomas et al. 1993; Cobbold et al. 1996). The Tien Shan mountain belts stretch 
east-west for more than $2,000 \mathrm{~km}$, with elevation exceeding 7,000 $\mathrm{m}$ in places (Nelson et al. 1987). The maximum topographic relief between the Fergana Valley floor with an altitude of roughly $450 \mathrm{~m}$ and the surrounding mountain peaks is about $4,500 \mathrm{~m}$.

The region around the Fergana basin can be divided into the following main geographical regions (after Burtman (1975); Cobbold et al. (1996); see Figure 1):

(1) The Chatkal range confines the study area to the north. Like the other ranges, the Chatkal range is formed by Paleozoic or older rocks (Thomas et al. 1993). The maximum elevation is about $4,500 \mathrm{~m}$ in this region. One of the major historic earthquakes, which occurred in 1946 with an $\mathrm{Mw}=7.3$ is located in the Chatkal region. Simpson et al. (1981) suggested that this earthquake was associated with the complex zone at the oblique intersection of the Talas-Fergana fault and Chatkal range.

(2) The Alai region with the Alai Valley (see Figure 1; SW Tien Shan), the Alai range north of the Alai Valley, and the Trans Alai Range south of the Alai Valley, which are all located to the south of the Fergana basin. The Trans Alai is already part of the Pamir mountains (Schurr et al. 2014).

(3) The Naryn basin, another major intermontane basin within the Tien Shan ranges, is located east of the study area. Like the Fergana basin, it is bounded on both sides by symmetric thrust zones with basinward vergences.

Because of the combined existence of shortening and shear mechanisms, the current tectonic context of the studied area is transpressional (Cobbold et al. 1996). The mountain ranges of the Tien Shan consist mainly of Paleozoic sedimentary rocks folded and faulted during the Carboniferous and Permian periods (Burtman 1975) where slip on gently dipping, east-west striking thrust faults accommodate north-south shortening (Nelson et al. 1987). In addition, a number of northwest-southeast trending dextral strike-slip faults (e.g., the Talas-Fergana fault) were active (Nelson et al. 1987). The Talas-Fergana fault (TFF) located east of the Fergana basin is one of the dominant tectonic structure in the study area. Its total offset is about $200 \mathrm{~km}$ since the Paleozoic. Paleomagnetic studies suggest that much, if not all, of this total offset occurred in the Cenozoic (Cobbold et al. 1996).

As one of the other important tectonic features of the Fergana basin, the major north-dipping reverse faults (North Fergana Fault, NFF) in the north and southdipping reverse faults (South Fergana Fault, SFF) in the south mark the edges of the basin (Chedia 1986; Judachin 1983; Osmonbetov et al. 1989; Cobbold et al. 1993).
The currently deforming Tien Shan is flanked by the relatively aseismic Siberian Shield to the north and the stable Tarim Basin to the south (Nelson et al. 1987).

\section{Previous investigations}

Based on permanent worldwide seismic networks, the local seismicity and the kinematics of the study region could be estimated. Most focal mechanisms derived in previous investigations indicate thrusting on faults trending east-west; some indicate strike-slip mechanisms. The direction of maximum shortening is approximately northsouth (Cobbold et al. 1996; Molnar et al. 1973; Ni 1978). Only very few large earthquakes in the Tien Shan show strike-slip mechanisms (Molnar et al. 1973; Ni 1978). Particularly, none of the events proximal to the Talas-Fergana fault show strike-slip mechanisms, suggesting that this fault is currently locked and that the present-day activity is being accommodated along the neighboring compressional structures (Ghose et al. 1998; Xu et al. 2006). Paleomagnetic studies concluded that the Fergana basin and the neighboring Chatkal Range have rotated $20^{\circ}$ to $30^{\circ}$ counterclockwise relative to Eurasia since the Paleocene (Bazhenov 1993; Thomas et al. 1993). The results of the work of Zubovich et al. (2010), analyzing the regional surface velocity field using GPS data, corroborate the inference that this basin might currently still rotate. Burtman (1980) analyzed the different stages of deformation in Central Asia and discussed the resulting fault network. In this study, a map of the major faults around the Fergana basin was published, which reveals the complexity of the faults in this region.

\section{Data}

A temporary local seismic array of 21 broadband stations (red triangles in Figure 1) was deployed in the Fergana region from September 2009 until September 2010 (Haberland et al. 2011). The network covered an area of $230 \times 180 \mathrm{~km}$ with an interstation distance of about 50 $\mathrm{km}$. Due to logistical reasons, the seismic network has been limited to the Kyrgyz territory and therefore does not cover the center of the Fergana basin, which is situated in Uzbekistan. All stations were equipped with a three-component broadband sensor (Güralp CMG ESP; Güralp Systems Ltd. Reading, UK) and a digital recorder (Earth Data PR6-24; Earth Data (part of Kenda Group), Southampton, UK) running at a sample rate of 100 sps. Accurate timing was provided by GPS. To extend the dataset, additional stations from other projects and permanent networks were used (TIPAGE, CAIAG, IRIS, PMP, CAREMON; blue triangles in Figure 1; Sippl et al. (2013)).

\section{Methods}

\section{Hypocenter location and velocity model}

Based on an earthquake catalog published by Sippl et al. (2013), we manually relocated 210 events that fell into 
our region of interest. Using 6,674 P- and 4,831 S-wave arrival times that were carefully hand-picked, the events were initially located with the program HYPO71 (Lee and Lahr 1972). An average of 23 P- picks per event (min: 8, max: 54) and an average azimuthal GAP of about $124^{\circ}$ ensure well-defined event locations. For the calculations of the initial hypocenters, we used a preliminary one-dimensional (1D) velocity model developed for the Pamir (Mechie et al. 2012).

P- and S- picks were weighted according to the estimated reading uncertainty of the phase arrival (quality class $0= \pm$ $0.01 \mathrm{~s} ; 1= \pm 0.05 \mathrm{~s} ; 2= \pm 0.1 \mathrm{~s} ; 3= \pm 0.2 \mathrm{~s} ; 4= \pm 0.3 \mathrm{~s} ;$ pick was not used for localization). In the second step, all manually picked arrival times ( $\mathrm{P}$ and $\mathrm{S}$ waves) were simultaneously inverted for the following:

(1) The hypocenter coordinates (latitude, longitude, depth, origin time)

(2) The one-dimensional velocity structure

(3) Station corrections using the program code VELEST (Kissling et al. 1995; see Figure 2).

The software code VELEST simultaneously locates earthquakes and calculates a vertically layered velocity model ( $\mathrm{Vp}$ and $\mathrm{Vp} / \mathrm{Vs}$ ) and station corrections. Due to the nonlinear character of the inverse problem, it iteratively calculates these parameters using a damped least squares inversion. In order to find the best solution by globally minimizing the travel time residuals, we ran many inversions starting from very different initial models following the procedure outlined by Kissling et al. (1994). First, we inverted for the optimal $\mathrm{Vp}$ model (keeping $\mathrm{Vp} / \mathrm{Vs}$ fixed at a value of 1.77 based on Wadati diagram analysis). After this, we fixed the thus obtained Vp model and inversion for the best-fit $\mathrm{Vp} / \mathrm{Vs}$ model, starting from a variety of initial values for $\mathrm{Vp} / \mathrm{Vs}$. This procedure proved to be robust in a number of previous studies (e.g., Haberland et al. 2007).

The resulting so-called minimum 1D model (Figure 2a and Table 1) is resolved down to approximately $40 \mathrm{~km}$ depth. The model shows gradually increasing seismic $\mathrm{p}$ velocities, starting with relatively high velocities around $5.8 \mathrm{~km} / \mathrm{s}$ at the surface and reaching roughly $7 \mathrm{~km} / \mathrm{s}$ at a depth between 40 and $50 \mathrm{~km}$. A velocity step related to the crust-mantle boundary was not detected due to the large crustal thickness and our restriction to use only observations with a maximum epicentral distance of 250 $\mathrm{km}$ to avoid complications with Pn-phases from our

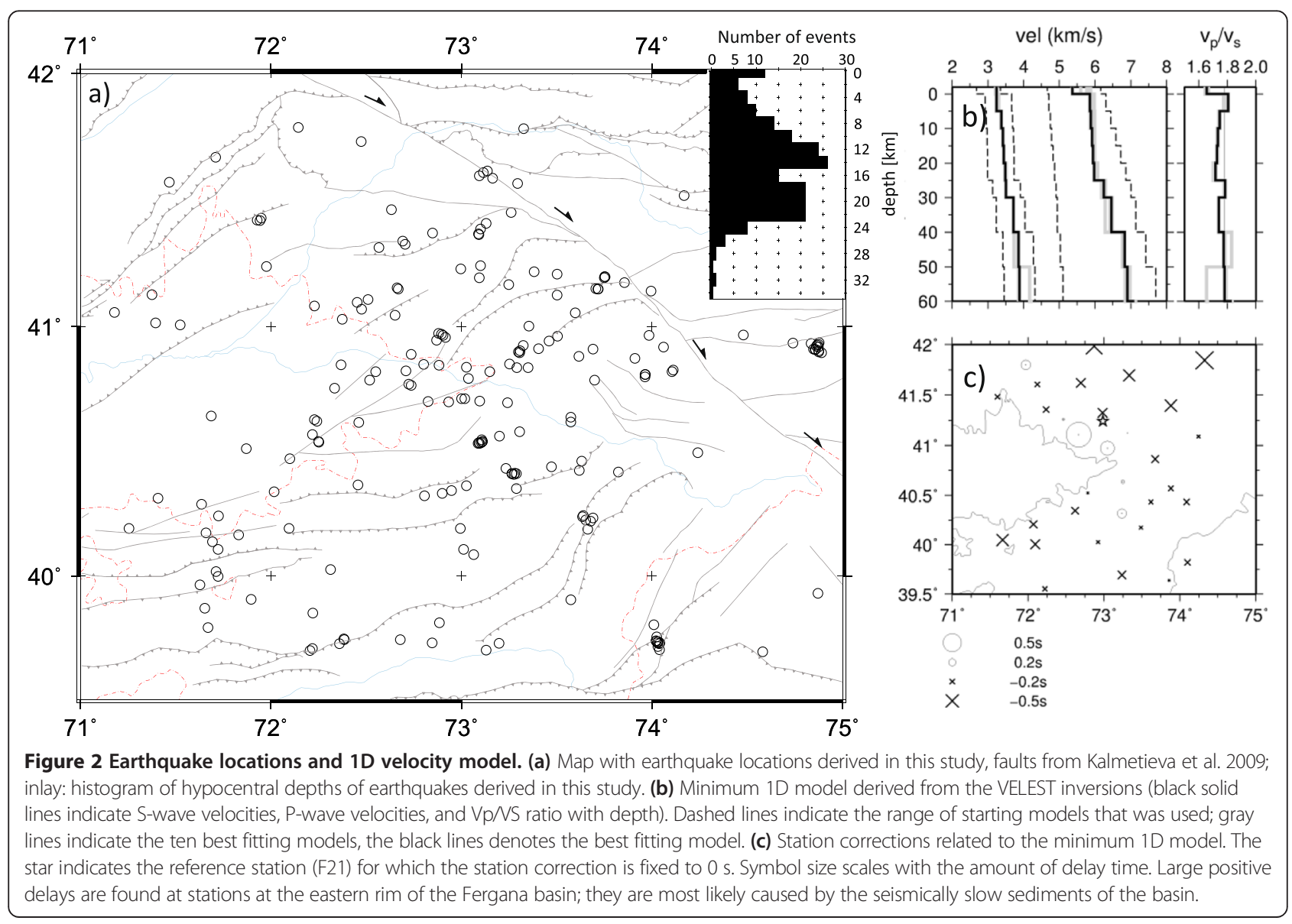


Table 1 Minimum 1D velocity model derived from the VELEST inversions

\begin{tabular}{lll}
\hline Depth $(\mathbf{k m})$ & $\mathbf{V p}(\mathbf{k m} / \mathbf{s})$ & Vs $(\mathbf{k m} / \mathbf{s})$ \\
\hline-5.00 & 5.36 & 3.24 \\
0.00 & 5.85 & 3.24 \\
5.00 & 5.88 & 3.37 \\
10.00 & 5.91 & 3.41 \\
15.00 & 5.94 & 3.44 \\
20.00 & 5.97 & 3.48 \\
25.00 & 6.24 & 3.50 \\
30.00 & 6.45 & 3.71 \\
40.00 & 6.83 & 3.85 \\
50.00 & 6.90 & 3.88 \\
\hline
\end{tabular}

See text for more details.

small to moderate magnitude earthquakes (lower signalto-noise ratio; often missed due to lower energy).

The $\mathrm{Vp} / \mathrm{Vs}$ ratios remain around 1.77 with only little variations (see Figure $2 \mathrm{~b}$ ). The $\mathrm{P}$ station corrections (station F21 was fixed, shown as star in Figure 2c) are mostly negative except for some stations at the eastern rim of the Fergana basin, and their values are usually smaller than $0.5 \mathrm{~s}$.

For the construction of the dam for the Kambar-Ata-2 hydroelectric power plant at the Naryn River in Kyrgyzstan, a strong explosion took place at 22 December 2009 05:54 (Mikhailova and Sinyova 2010). Since the origin time and exact location of the explosion are known, we use them to estimate the uncertainties of the location method employed in this study and to estimate the differences to locations from global networks. The comparison of the exact origin time and locations, shown in Table 2, reveals a very accurate location of the earthquakes derived by this study and a significant improvement of the locations compared to the ones derived from global networks (epicentral distance is about ten times more accurately derived from this study compared to locations derived from global networks, Table 2). Based on these estimates, we assume a horizontal and vertical accuracy of our earthquake locations in the range of $1 \mathrm{~km}$.

\section{Fault plane solutions from first motion polarities}

To calculate fault plane solutions using first motion polarities (FMP), the Fortran program FPFIT (Reasenberg and Oppenheimer 1985) was used. The program FPFIT finds the double couple fault plane solution that best fits a given set of observed first motion polarities for an earthquake. The inversion is accomplished through a two-stage grid search procedure which selects the source model by minimizing a normalized weighted sum of first motion polarity discrepancies. Using a minimum of 7 first motion polarities per event (in average 13), a total of 31 unambiguous fault plane solutions were determined. From the 31 stable solutions, 16 show reverse fault or oblique reverse fault characteristics, whereas 13 exhibit strike-slip mechanisms. Two of the calculated fault plane solutions show an oblique normal faulting mechanism. The results are listed in Table 3 and shown in Figure 3 as a map view and in Figure 4 as a catalog with picked polarities.

\section{Waveform inversion for moment tensor}

In total, nine moment tensors were calculated by waveform inversion, modeling the entire local and regional three-component seismograms, following the procedure described by Nabelek and Xia (1995). The results of the moment tensor inversion are listed in Table 4 and shown in Figure 3. Prior to the inversion, the instrument response is removed from the data before the data are bandpass-filtered, down-sampled and rotated into a ray coordinate system (ZRT). Stations which have an insufficient signal-to-noise ratio or were clipped were excluded from the inversion. Green's functions including nearfield terms were calculated using the derived $1 D$ velocity model (see above). Bandpass filtering was individually adjusted to maximize the signal-to-noise ratio at the lowest possible frequencies; typical filter bands were 10 to $50 \mathrm{~s}$ for events with $\mathrm{Mw}>4$ and 10 to $30 \mathrm{~s}$ for smaller magnitudes.

Table 2 The relocation of the Kambar-Ata-2 explosion using the minimum 1D model (Table 1)

\begin{tabular}{lllllll}
\hline Source & Origin time & Lon $\left({ }^{\circ} \mathrm{E}\right)$ & $\mathbf{U t m}^{\mathbf{a}} \boldsymbol{X}(\mathbf{k m})$ & Lat $\left({ }^{\circ} \mathbf{N}\right)$ & Utm $^{\mathbf{a}} \boldsymbol{Y}(\mathbf{k m})$ & $\mathbf{D e p t h}(\mathbf{k m})$ \\
\hline Exact parameters & 22 December 2009 05:54:33.645 & 73.3332 & $361,472.788$ & 41.7753 & $4,626,171.120$ & -0.920 \\
Minimum 1D model & 22 December 2009 05:54:33.99 & 73.3257 & $360,865.879$ & 41.7829 & $4,627,027.059$ & -0.190 \\
Difference & $0.345 \mathrm{~s}$ & & $-606 \mathrm{~m}$ & & $855 \mathrm{~m}$ & 0.730 \\
NEIC PDE & 22 December 2009 05:54:35.020 & 73.42 & 368,493 & 41.68 & $4,615,454$ & 10 \\
Difference & $1.375 \mathrm{~s}$ & & $10,717 \mathrm{~m}$ & & $-7,020 \mathrm{~m}$ & 10.92 \\
GEOFON & 22 December 2009 05:54:38.300 & 73.30 & 358,988 & 41.90 & $4,640,071$ & 10 \\
Difference & $4.655 \mathrm{~s}$ & & $-13,899 \mathrm{~m}$ & & $2,484 \mathrm{~m}$ & 10.92 \\
\hline
\end{tabular}

${ }^{a}$ UTM zone 43. The horizontal mislocation of this explosion is 1,047 $\mathrm{m}$; the vertical mislocation is $730 \mathrm{~m}$. Exact parameters from Mikhailova and Sinyova (2010). In addition, the exact parameters are compared to the location of the Preliminary Determinations of Epicenters (PDE) and GEOFON catalog (differences relative to exact location). See text for more details. 
Table 3 Source parameters of earthquakes in the Fergana region from first motion polarities (no. 1 to no. 31 )

\begin{tabular}{|c|c|c|c|c|c|c|c|c|c|c|c|}
\hline Number & $\begin{array}{l}\text { Date } \\
\text { [YY/MM/DD] }\end{array}$ & $\begin{array}{l}\text { Origin } \\
\text { [HH:MM] }\end{array}$ & $\begin{array}{l}\text { Time (UT) } \\
\text { [SS.SS] }\end{array}$ & $\begin{array}{l}\text { Lat } \\
{\left[{ }^{\circ} \mathrm{N}\right]}\end{array}$ & $\begin{array}{l}\text { Lon } \\
{\left[{ }^{\circ} \mathrm{E}\right]}\end{array}$ & $\begin{array}{l}\text { Depth } \\
{[\mathrm{km}]}\end{array}$ & $\begin{array}{l}\text { GAP } \\
{\left[{ }^{\circ}\right]}\end{array}$ & $\begin{array}{l}\text { Strike } \\
{\left[{ }^{\circ}\right]}\end{array}$ & $\begin{array}{l}\text { Dip } \\
{\left[^{\circ}\right]}\end{array}$ & $\begin{array}{l}\text { Rake } \\
{\left[{ }^{\circ}\right]}\end{array}$ & Mechanism \\
\hline 1 & $09 / 09 / 19$ & $20: 09$ & 28.66 & 41.6098 & 73.1152 & 21.77 & 113 & 20 & 80 & -10 & Strike-slip fault \\
\hline 2 & $09 / 09 / 22$ & $22: 44$ & 41.48 & 41.0019 & 73.354 & 15.63 & 37 & 75 & 45 & 100 & Reverse fault \\
\hline 3 & 09/09/30 & 09:48 & 3.29 & 40.1666 & 71.8302 & 25.23 & 75 & 40 & 60 & 40 & Oblique reverse fault \\
\hline 4 & 09/09/30 & 19:02 & 51.66 & 40.8738 & 73.9114 & 14.33 & 92 & 5 & 75 & 0 & Strike-slip fault \\
\hline 5 & 09/10/14 & $17: 37$ & 20.19 & 39.7369 & 74.0231 & 7.56 & 160 & 125 & 65 & 120 & Oblique reverse fault \\
\hline 6 & 09/10/16 & 14:24 & 2.14 & 39.742 & 72.3838 & 15.04 & 42 & 270 & 67 & -136 & Oblique normal fault \\
\hline 7 & $09 / 10 / 20$ & $21: 48$ & 22.76 & 40.5372 & 73.091 & 8.45 & 62 & 95 & 85 & -180 & Strike-slip fault \\
\hline 8 & $09 / 10 / 28$ & $08: 36$ & 6.28 & 41.2079 & 73.5018 & 21.09 & 48 & 301 & 50 & 173 & Strike-slip fault \\
\hline 9 & $09 / 10 / 28$ & $22: 44$ & 22.04 & 41.1942 & 73.0931 & 18.95 & 54 & 20 & 65 & 50 & Oblique reverse fault \\
\hline 10 & $09 / 11 / 16$ & $23: 36$ & 2.3 & 40.4128 & 73.2648 & 5.95 & 53 & 5 & 30 & 100 & Reverse fault \\
\hline 11 & $09 / 11 / 18$ & $15: 42$ & 26.29 & 40.8085 & 73.9635 & 12.09 & 79 & 75 & 45 & 40 & Oblique reverse fault \\
\hline 12 & $09 / 11 / 21$ & $22: 36$ & 54.02 & 40.9425 & 73.4597 & 17.6 & 49 & 5 & 85 & 0 & Strike-slip fault \\
\hline 13 & $09 / 12 / 08$ & $01: 28$ & 6.56 & 40.8962 & 73.3061 & 16.27 & 58 & 85 & 90 & -170 & Strike-slip fault \\
\hline 14 & $09 / 12 / 27$ & 13:07 & 41.95 & 40.6378 & 73.5735 & 17.6 & 62 & 220 & 85 & -30 & Strike-slip fault \\
\hline 15 & $09 / 12 / 27$ & $17: 07$ & 33.29 & 40.1917 & 72.9949 & 22.58 & 66 & 100 & 25 & 120 & Reverse fault \\
\hline 16 & $10 / 01 / 04$ & $00: 16$ & 38.2 & 39.803 & 74.0098 & 10.91 & 132 & 140 & 85 & 170 & Strike-slip fault \\
\hline 17 & $10 / 01 / 31$ & $02: 56$ & 28.84 & 41.463 & 72.6321 & 15.9 & 85 & -5 & 30 & 50 & Oblique reverse fault \\
\hline 18 & $10 / 02 / 06$ & $20: 26$ & 54.46 & 40.8206 & 74.1058 & 12.77 & 96 & 55 & 40 & 110 & Reverse fault \\
\hline 19 & $10 / 03 / 10$ & $21: 17$ & 5.94 & 40.8206 & 73.1483 & 14.05 & 64 & -85 & 75 & 170 & Strike-slip fault \\
\hline 20 & $10 / 05 / 05$ & $11: 41$ & 46.96 & 40.3524 & 73.2872 & 10.99 & 58 & 120 & 55 & 140 & Oblique reverse fault \\
\hline 21 & $10 / 05 / 06$ & $20: 07$ & 5.7 & 40.926 & 74.867 & 11.92 & 119 & 45 & 90 & -20 & Strike-slip fault \\
\hline 22 & $10 / 05 / 06$ & $20: 23$ & 4.94 & 40.9042 & 74.8761 & 9 & 119 & 45 & 90 & -30 & Strike-slip fault \\
\hline 23 & $10 / 05 / 11$ & $22: 58$ & 31.71 & 41.4227 & 71.9266 & 23.05 & 114 & 60 & 60 & 80 & Reverse fault \\
\hline 24 & $10 / 05 / 16$ & $22: 38$ & 26.71 & 41.0542 & 73.5965 & 17.43 & 63 & 55 & 70 & 60 & Oblique reverse fault \\
\hline 25 & $10 / 06 / 10$ & $06: 38$ & 4.69 & 39.9304 & 74.8708 & 19.9 & 203 & 65 & 45 & 80 & Reverse fault \\
\hline 26 & 10/07/06 & 00:06 & 38.88 & 40.7708 & 72.7223 & 18.52 & 81 & 85 & 55 & 70 & Reverse fault \\
\hline 27 & 10/07/07 & 02:03 & 44.74 & 40.6285 & 72.2284 & 23.63 & 113 & 253 & 66 & 39 & Oblique reverse fault \\
\hline 28 & 10/07/07 & $17: 03$ & 2 & 40.6169 & 72.4597 & 25.13 & 95 & 35 & 25 & 90 & Reverse fault \\
\hline 29 & 10/07/09 & $02: 48$ & 2.62 & 40.1738 & 71.6593 & 21.63 & 180 & 3 & 83 & -45 & Oblique normal fault \\
\hline 30 & $10 / 07 / 15$ & 02:07 & 10.4 & 40.851 & 73.2529 & 16.51 & 104 & -5 & 80 & 30 & Strike-slip fault \\
\hline 31 & 10/09/04 & 21:17 & 41.58 & 40.8816 & 73.6162 & 8.37 & 86 & 40 & 70 & 30 & Strike-slip fault \\
\hline
\end{tabular}

Figure 5 shows synthetic (red dashed lines) and observed (black solid lines) displacement seismograms for an Mw 4.3 event on 11 May 2010. The synthetic seismograms were realigned in time, which accounts for the deviations of the real velocity structure from the assumed $1 \mathrm{D}$ velocity model, so the size of the alignment time correction can be an indication for the validity of the velocity model at distant regions. Since all time shifts show negative values with an average of $-4.2 \mathrm{~s}$, the velocity model is suggested to be systematically fast. This is also indicated by the initial 1D velocity model (Figure 2c).

The inversion is performed for a set of trial depths, and the best solution is defined as the one with the maximum variance reduction. The resulting variance vs. depth diagram indicates the optimal depth as a clear variance minimum (Figure 5). This method is quite insensitive to inaccurate Green's functions. The misfit between data and synthetics is often projected into the CLVD component of the moment tensor, leaving the DC parameters strike, dip, and rake relatively undisturbed (Schurr and Nabelek 1999).

\section{Stress tensor}

To investigate the stress regime of the region, we did a stress tensor inversion of the three principal stresses $(\sigma 1=$ 


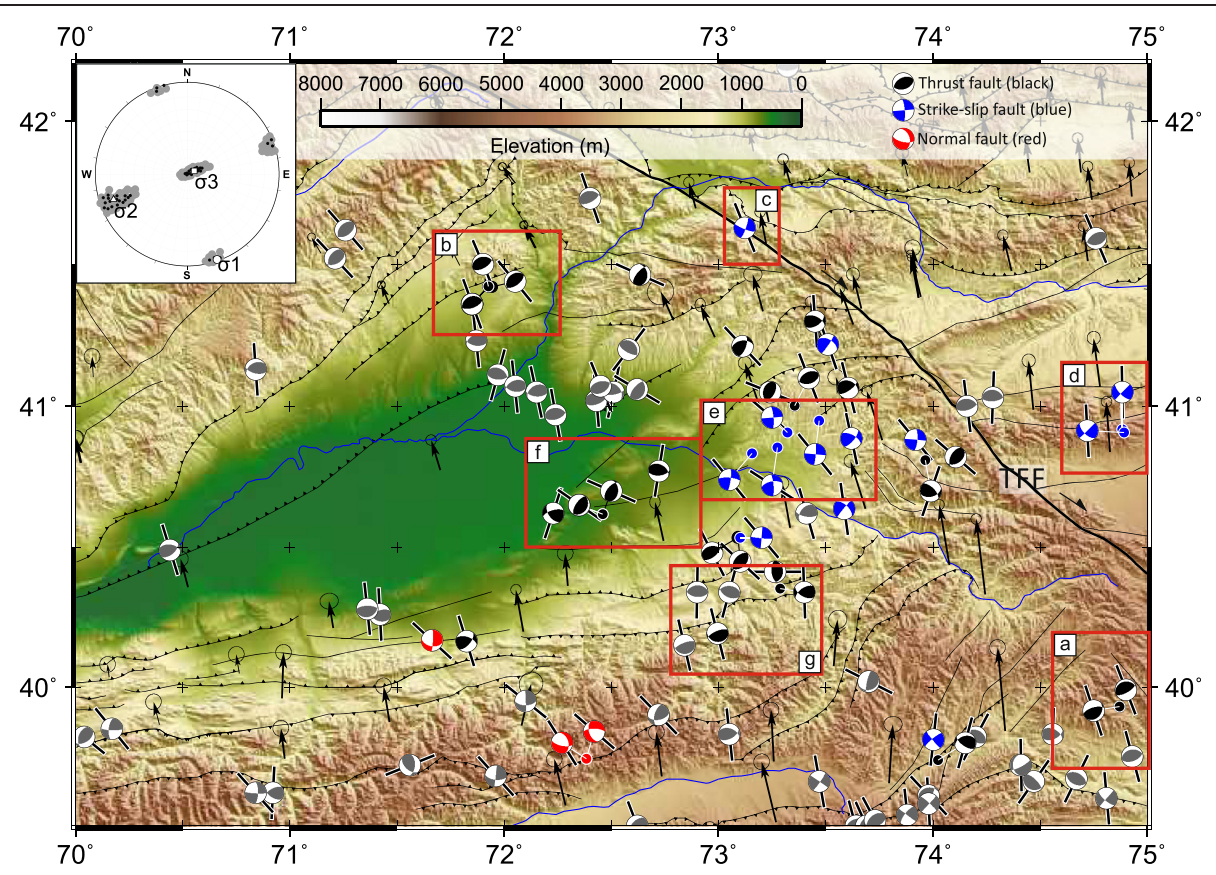

Figure 3 Fault plane solutions. Fault plane solutions derived in this study (black, blue, red; color coded by their mechanism) and taken from the global CMT catalog and Ghose et al. 1998 (gray) overlaid on a topographic map showing the known tectonic structures of the region. Bars under the fault plane solutions indicate the orientation of the axis of maximum compressional deformation ( $P$ axis); arrows indicate velocity field relative to stable Eurasia from GPS data (Zubovich et al. 2010); faults taken from Kalmetieva et al. 2009. Red boxes (a to e) indicate clusters of earthquakes discussed in the text. Inlay: result from stress tensor inversion; bright gray dots show results within a $95 \%$ confidence interval and dark gray dots show results within a 68\% confidence interval. The best fit is shown by a white triangle for stress axis $\sigma 2$, a white square for $\sigma 3$, and the white dot for $\sigma 1$. The stress inversion was performed using previously known data (Global CMT catalog, Ghose et al. (1998)) and solutions derived in this study (total no. of observations: 109). The derived best-fit stress tensor shows a clear thrust mechanism with well-defined $\sigma 2, \sigma 3$, and $\sigma 1$ with a direction of $160^{\circ} / 340^{\circ}$. TFF, Talas-Fergana Fault.

maximum compressive stress, $\sigma 2=$ intermediate, and $\sigma 3=$ minimum) and the stress ratio.

$$
R=(\sigma 2-\sigma 3) /(\sigma 1-\sigma 3), 0<R<1
$$

with $R<0.5$ and $R>0.5$ indicating a transpressional and transtensional regime, respectively. We applied the linear inversion algorithm of Michael (1984, 1987) using focal mechanism data as input and assuming a random stress tensor derived by a least square method. The result shown in the inlay of Figure 3 is calculated based on 109 fault plane solutions consisting of 35 fault plane solutions derived in this study and 74 fault plane solutions from the Global CMT catalog (Dziewonski et al. 1981; Ekström et al. 2012) and Ghose et al. 1998.

\section{Results and discussion}

Most of the small-magnitude local earthquakes are found at depths between 2 and $25 \mathrm{~km}$ at the edge of the Fergana basin and beneath the surrounding mountain areas, with a concentration in the eastern part of the study area. Fewer earthquakes occur within the basin. This concentration of earthquakes east of the Fergana basin coincides with the concentration of faults mapped at the surface. The faults in this zone trend predominantly WSW-ENE and indicate the eastern termination of the basin. The basin itself is bounded to the north and south by roughly WSW-ENE trending, north-vergent and south-vergent thrust faults, respectively, which continue eastward and spread into a rather broad zone of several sub-parallel faults (see Figure 3).

Fault plane solutions, both from first motion polarities and from waveform inversion, show a majority of thrust mechanisms followed by strike-slip mechanisms. NW-SE shortening with a strike-slip shear component resulting in oblique shear is the dominant component of the derived large-scale stress regime. The fault plane solutions of this study and those from Ghose et al. (1998) and $\mathrm{Ni}$ (1978) are very consistent. Moreover, the earthquake mechanisms and the derived stress field are in good agreement with the regional tectonic setting, which is dominated by NW-SE compression (Cobbold et al. 1996; Buslov et al. 2003, 2007).

The calculated stress tensor (Figure 3 inlay) shows well-defined orientations for $\sigma 1, \sigma 2$, and $\sigma 3$. The axis of maximum stress (s1) lies in the horizontal plane and the 

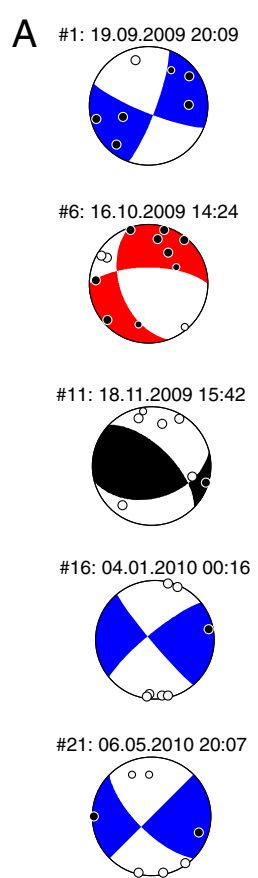

\#26: 06.07.2010 00:06

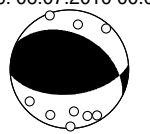

\#28: 07.07.2010 17:03

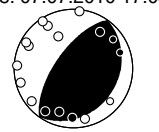

\#30: 15.07.2010 02:07

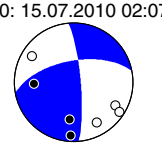

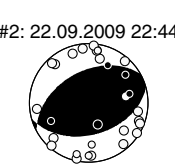

\#7: 20.10.2009 21:48

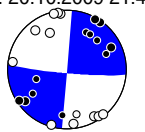

\#12: 21.11.2009 22:36
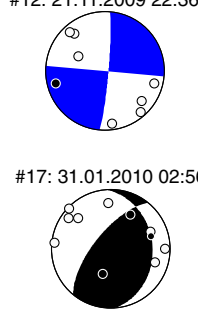

\#22: 06.05.2010 20:23

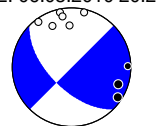

\#27: 07.07.2010 02:03

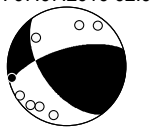

\#29: 09.07.2010 02:48

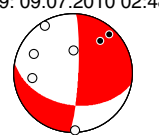

\#31: 04.09.2010 21:17

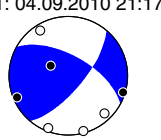

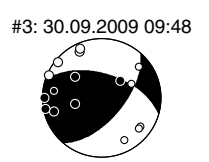

\#8: 28.10.2009 08:36

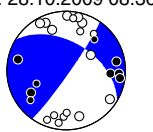

\#13: 08.12.2009 01:28
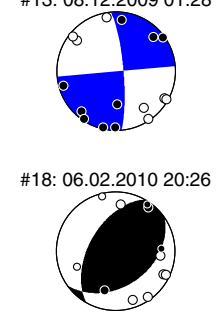

\#23: 11.05 .2010 22:58
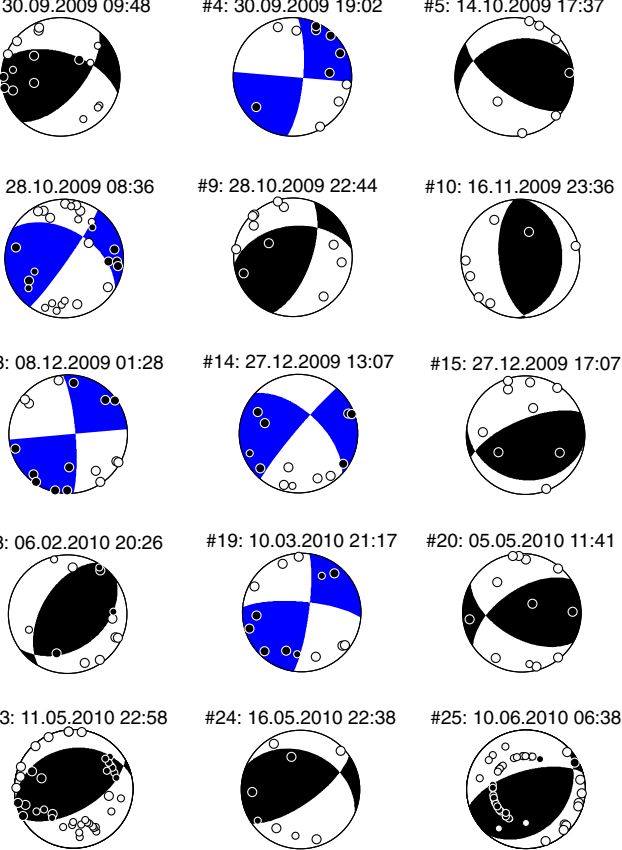

\#24: 16.05.2010 22:38
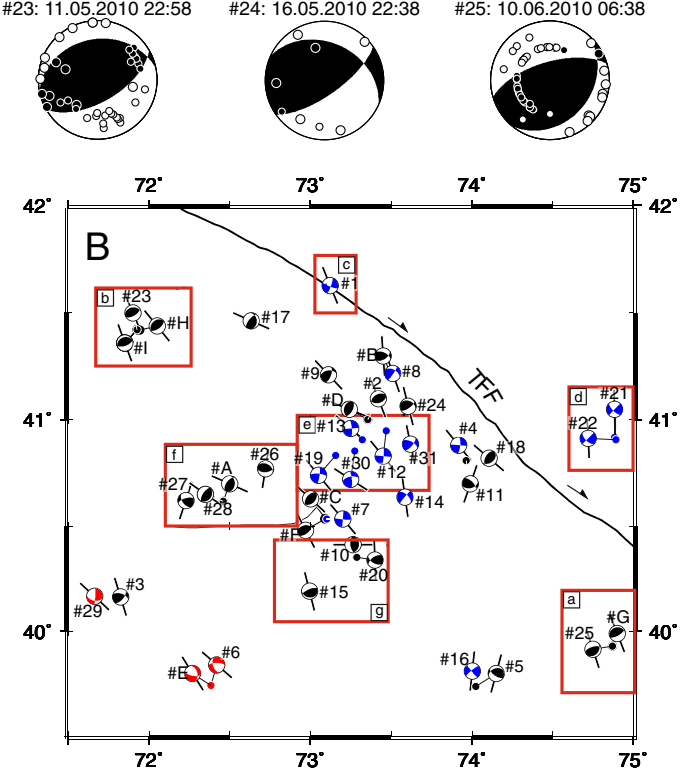

Figure 4 Fault plane solution catalog with picked polarities. (A) Fault plane solutions derived in this study (based on first motion polarities), color coded by their mechanism (black = thrust mechanism, blue = strike-slip mechanism, red = normal mechanism) with picked polarities plotted on the focal mechanisms (black dots correspond to positive polarities; white dots correspond to negative polarities), labeled as shown in Table 3. (B) Map view of fault plane solutions derived in this study (based on first motion polarities and moment tensor inversion), labeled as shown in Tables 3 and 4.

axis of minimum stress (s3) in the vertical plane indicating thrust faulting. The stress ratio of $R=0.19$ implies a transpressional tectonic regime (Michael 1984, 1987), which is in line with the already described tectonic context (Cobbold et al. 1996). The evaluation of the derived stress tensor reveals predominately thrust faulting where the principal compressive stress axis has a direction of $340^{\circ}$ (NNW-SSE) combined with strike-slip components. A large proportion of the hypocenters are co-located with the faults mapped at the surface, although the earthquakes hardly delineate them clearly. This is most likely due to the short operation period of the FERGANA network limited to 1 year, implying that not enough earthquakes were captured.

Nevertheless, it seems that the earthquakes indicate broadly distributed deformation in this eastern part of the study region, while to the north and south the deformation seems to be confined to the boundary faults of the basin.

The earthquake catalog from Simpson et al. 1987 which contains earthquake data from 1962 to 1985 shows a broad spatial distribution in the study area with slight 
Table 4 Source parameters of earthquakes in the Fergana region from moment tensor inversion (A to I)

\begin{tabular}{|c|c|c|c|c|c|c|c|c|c|c|c|c|}
\hline Number & $\begin{array}{l}\text { Date } \\
\text { [YY/MM/DD] }\end{array}$ & $\begin{array}{l}\text { Origin } \\
\text { [HH:MM] }\end{array}$ & $\begin{array}{l}\text { Time (UT) } \\
\text { [SS.SS] }\end{array}$ & $\begin{array}{l}\text { Lat } \\
{\left[{ }^{\circ} \mathrm{N}\right]}\end{array}$ & $\begin{array}{l}\text { Lon } \\
{\left[{ }^{\circ} \mathrm{E}\right]}\end{array}$ & $\begin{array}{l}\text { Depth } \\
{[\mathrm{km}]}\end{array}$ & $\begin{array}{l}\text { GAP } \\
{\left[{ }^{\circ}\right]}\end{array}$ & $M w$ & $\begin{array}{l}\text { Strike } \\
{\left[{ }^{\circ}\right]}\end{array}$ & $\begin{array}{l}\text { Dip } \\
{\left[^{\circ}\right]}\end{array}$ & $\begin{array}{l}\text { Rake } \\
{\left[{ }^{\circ}\right]}\end{array}$ & $\begin{array}{l}\text { Norm } \\
\text { Var } \\
\end{array}$ \\
\hline $\bar{A}$ & $10 / 07 / 07$ & 17:03 & 2 & 40.6169 & 72.4597 & 24 & 96 & 3.63 & 218 & 57 & 110 & 0.6851 \\
\hline B & $09 / 10 / 28$ & $08: 36$ & 6.28 & 41.2079 & 73.5018 & 18 & 48 & 3.82 & 57 & 54 & 46 & 0.792 \\
\hline C & $09 / 10 / 20$ & $21: 48$ & 22.76 & 40.5372 & 73.091 & 4 & 62 & 3.56 & 220 & 49 & 86 & 0.5668 \\
\hline D & $09 / 09 / 22$ & $22: 44$ & 41.48 & 41.0019 & 73.354 & 12 & 37 & 3.51 & 30 & 56 & 101 & 0.5496 \\
\hline$E$ & $09 / 10 / 16$ & 14:24 & 2.14 & 39.742 & 72.3838 & 18 & 42 & 3.34 & 102 & 66 & -125 & 0.6343 \\
\hline $\mathrm{F}$ & 09/11/11 & $02: 40$ & 3.13 & 40.5342 & 73.0873 & 4 & 42 & 3.61 & 49 & 58 & 70 & 0.5044 \\
\hline G & 10/06/10 & $06: 38$ & 4.69 & 39.9304 & 74.8708 & 21 & 202 & 4.9 & 61 & 68 & 82 & 0.3297 \\
\hline $\mathrm{H}$ & $10 / 05 / 11$ & 23:07 & 21.5 & 41.4198 & 71.9428 & 21 & 110 & 3.36 & 55 & 58 & 95 & 0.6376 \\
\hline I & 10/05/11 & $22: 58$ & 31.71 & 41.4227 & 71.9266 & 18 & 117 & 4.33 & 70 & 61 & 91 & 0.463 \\
\hline
\end{tabular}

concentration of earthquake activity east of the Fergana basin and fewer events within the basin. These observations are confirmed by the spatial distribution presented in this study. The earthquake clusters and events labeled in Figure 3 and discussed in the following chapter are not recovered by the earthquake catalog from Simpson et al. 1987, which shows more a widespread spatial distribution of earthquake locations than defining known local faults.

\section{Thrust faults}

Examples of clusters of events co-located with known thrust faults are found in the southeastern part of the study area. Here, the strongest event during the network operation occurred on 10 June 2010 06:38 with a magnitude of $\mathrm{Mw}=4.9$ (from moment tensor inversion). Both focal mechanisms from FMP and waveform inversion show a clear thrust mechanism for this event (Figure 3, box a), which took place at a depth of about $20 \mathrm{~km}$ (Table 3, no. 25 and Table 4, G; Figure 3 box a; strike $=$ $65^{\circ}$, dip $=45^{\circ}$, rake $=80^{\circ}$, see Figure 4 for exact epicenter position). Moreover, the CMT solution likewise is in good agreement with these derived values, although the hypocentral position of the CMT solution is $20 \mathrm{~km}$ off. It is conceivable that the earthquake happened at the south-dipping thrust fault which is mapped at the surface around $25 \mathrm{~km}$ to the north of the hypocenter. In this case, the hypocenter location would be in agreement with a southward fault dip of around $40^{\circ}$.

Another example for thrust events is the cluster in the northwestern part of the study area in close proximity to the North Fergana fault (Table 3, no. 23, Table 4, H and I; Figure 3, box b). These earthquakes occurred at depths of 18 to $24 \mathrm{~km}$. Focal mechanisms from both FMP and waveform inversion consistently show thrust mechanisms (strike $=60^{\circ}$, dip $=60^{\circ}$, rake $=80^{\circ}$ ), which could indicate that the events occurred on a thrust fault running sub-parallel to the north-vergent North Fergana fault (NFF) or on the NFF itself (Chedia 1986).
At the eastern rim of the Fergana basin, some events with oblique reverse and reverse mechanism occurred (Figure 3, box f). These events can be related to a regional system of NE-SW striking thrust faults, which dips steeply to N-NW. According to Chedia 1986, these faults named South-Kuvin fault and North-Kuvin fault have a vertical offset of about 8 to $10 \mathrm{~km}$. Box g in Figure 3 shows the area of the South Nookat fault, Aldiyar fault system, and the northern boundary of the Aldiyar block (Chedia 1986). These NE-SW striking thrust faults, which are dipping to the south, have been identified as the potential structural framework for accommodating these earthquakes with reverse character shown here.

\section{Strike-slip faults}

The observed seismicity along the TFF, a prominent dissection of the region, is very sparse, suggesting that this fault is presently locked or aseismically creeping. This has also been concluded by Ghose et al. (1998) based on the analysis of teleseismic events. Only one earthquake cluster could be detected in the northern part of the fault. For the strongest earthquake of this cluster, we could determine a fault plane solution from FMP with a clear strike-slip mechanism (Table 3, no. 1; Figure 3, box c; strike $=20^{\circ}$, dip $=80^{\circ}$, rake $=-10^{\circ}$ ). The strike direction of approximately $20^{\circ}$ is in good agreement with the strike of the TFF.

In contrast to teleseismic catalogs, while listing almost exclusively thrust events (Global CMT catalog, Ghose et al. 1998; Ni 1978), we notice a relatively large proportion of strike-slip events in the region, however, off the TFF.

A prominent earthquake sequence could be observed in the east of the study area (Figure 3, box d). This cluster has a pronounced NW-SE elongated shape in map view, with a length of about $10 \mathrm{~km}$. The cluster is located at a depth between 10 and $12 \mathrm{~km}$. The fault plane solutions (FPS) of three earthquakes of this cluster show 


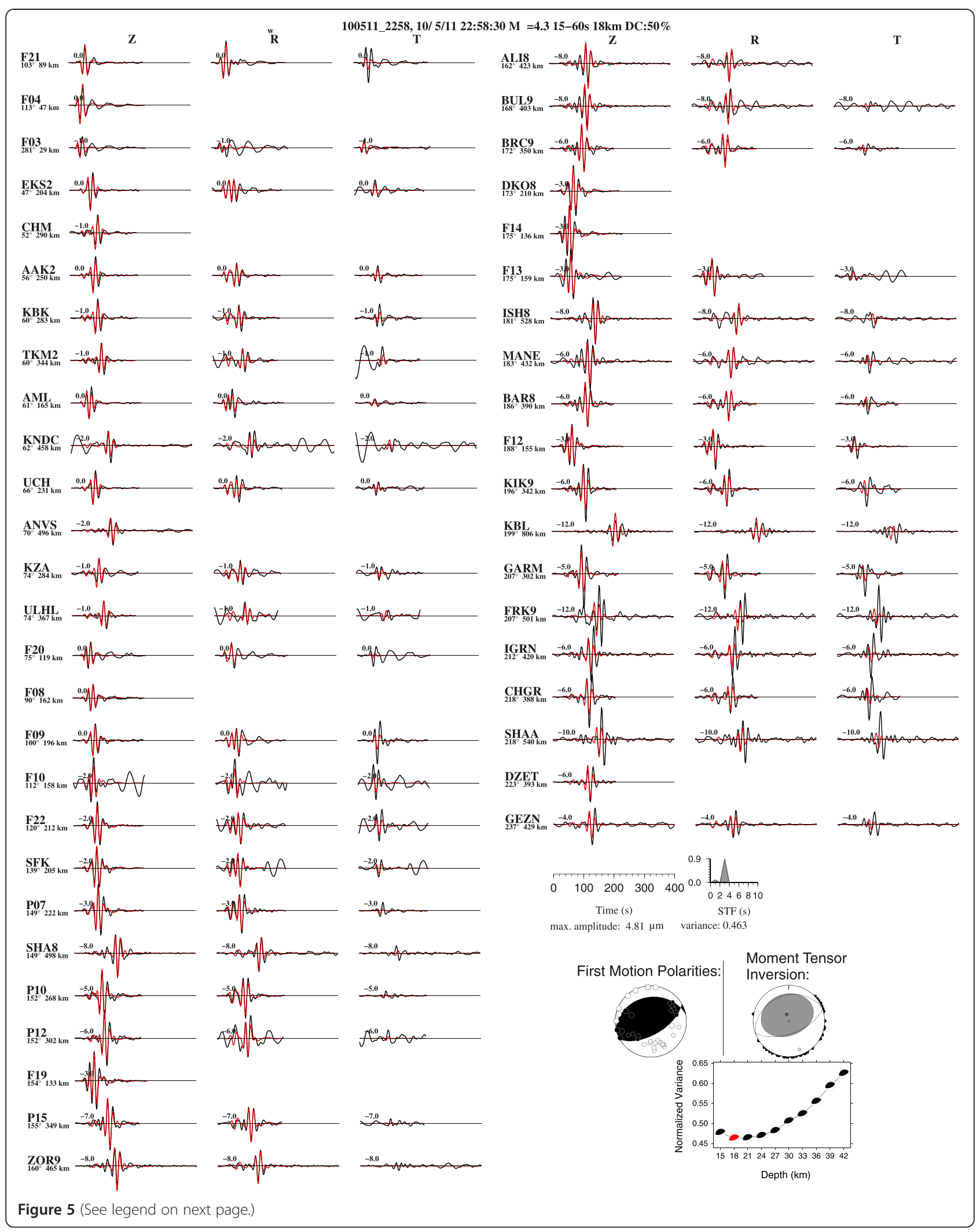


(See figure on previous page.)

Figure 5 Waveform data used for the moment tensor inversion (11 May 2010 22:58 event). Synthetic (red, dashed) and observed (black, solid) waveforms used for moment tensor inversion for vertical (Z), transverse (T), and radial (R) components of the 11 May $201022: 58$ event. The applied alignment time correction is indicated by the number next to the seismogram. It spans from $0.0 \mathrm{~s}$ for near stations to $-12.0 \mathrm{~s}$ for distant stations. The epicentral distance of the station is shown beneath the station name. A variance versus depth diagram from the moment tensor inversion yields the optimum solution as a clear minimum (red focal mechanism) at $18 \mathrm{~km}$ depth. The large black beach ball shows the solution from First Motion Polarities of the same event, compare the mechanism to the one derived from waveform inversion to its right. Black dots inside the FMP beach ball denote positive P polarity picks, white dots are negative ones.

clear strike-slip mechanisms (Table 2, nos. 21 and 22; strike approximately $45^{\circ}$; dip approximately $90^{\circ}$, rake approximately -20 to $-30^{\circ}$ ). The consistent strike directions of the FPS and the alignment of the hypocenter locations indicate an activity along a NW-SE trending fault plane which is sub-parallel to the TFF. However, the cluster is located roughly $40 \mathrm{~km}$ east of the TFF. To our knowledge, this potential fault has not been mapped yet at the surface. It is conceivable that part of the strike-slip deformation in the region is now accommodated along faults parallel to the TFF and not along the TFF itself.

More strike-slip events are found in the seismically active region directly east of the Fergana basin. Here, we identified several events (Table 2, nos. 19, 30, 13, 12; Figure 3, box e) with strike-slip mechanisms (strike approximately $0^{\circ}$; dip approximately $85^{\circ}$; rake approximately $\left.0^{\circ}\right)$. These events are located at a depth of about 16 to 20 $\mathrm{km}$. Based on our limited data, it is not possible to infer the rupture plane(s), so both north-south and west-east trending fault planes are conceivable. More detailed in situ investigations of active structures would be required to decide which of the nodal planes the actual fault plane is. In this context, the NE-SW striking fault system of MadinTaldi-Suu (Chedia 1986) could have possibly hosted these earthquakes.

\section{Conclusions}

The 1-year deployment of the FERGANA local seismic network was used to detect 210 diffusely distributed earthquakes in the Fergana region, with a magnitude range from 1.9 to $5.5(\mathrm{ML})$. The seismicity delineates a complex tectonic setting with activity spread out over many small faults; some of them had been mapped before and could hence be verified as currently active. In contrast to the high seismicity rate within the Fergana basin derived by global networks, the seismicity derived from this study tends to be high at the edge of the basin and in mountain areas and rather sparse within the basin. The assumption of a locked Talas-Fergana fault (Ghose et al. 1998) can be confirmed by this study, with a notably low seismicity rate along this structure. Although the spatial distribution of seismicity is not completely uniform, no single predominant fault or structure absorbs the majority of seismic energy.

The known origin time and location of an explosion provide ground truth evidence for a significant improvement of the accuracy of earthquake locations in the Fergana region. With our local network, we achieved a horizontal and vertical accuracy of about $1 \mathrm{~km}$, which is significantly higher than the accuracy which is obtained for locations derived from global networks (approximately 12 to $15 \mathrm{~km}$ ). The comparison of four earthquake locations from global catalogs and the corresponding

Table 5 Comparison of source parameters determined by different catalogs

\begin{tabular}{|c|c|c|c|c|c|c|c|c|}
\hline \multirow[t]{2}{*}{ PDE/This study (TS) } & Date & Origin & Time (UT) & Lat & Lon & Depth & Mag & $\begin{array}{l}\text { Epicenter difference to location } \\
\text { derived in this study }\end{array}$ \\
\hline & [YY/MM/DD] & [HH:MM] & [SS.SS] & {$\left[{ }^{\circ} \mathrm{N}\right]$} & {$\left[{ }^{\circ} \mathrm{E}\right]$} & {$[\mathrm{km}]$} & & {$[\mathrm{km}]$} \\
\hline PDE & 09/10/28 & $08: 36$ & 12.0 & 41.435 & 73.216 & 35.0 & 4.5 & 34.746 \\
\hline TS & 09/10/28 & $08: 36$ & 6.28 & 41.2079 & 73.5018 & 21.09 & & \\
\hline PDE & $09 / 11 / 11$ & $02: 40$ & 8.5 & 40.632 & 73.041 & 43.9 & 4.2 & 11.868 \\
\hline TS & 09/11/11 & $02: 40$ & 3.13 & 40.5342 & 73.0873 & 2.92 & & \\
\hline PDE & 10/05/11 & $22: 58$ & 34.4 & 41.445 & 71.825 & 33.9 & 4.9 & 8.847 \\
\hline Geofon & $10 / 05 / 11$ & $22: 58$ & 33.5 & 41.45 & 71.99 & 24 & 4.9 & 6.134 \\
\hline TS & $10 / 05 / 11$ & $22: 58$ & 31.71 & 41.422 & 71.9266 & 23.05 & & \\
\hline PDE & $10 / 06 / 10$ & $06: 38$ & 5.4 & 39.865 & 74.846 & 28.6 & 5.5 & 7.573 \\
\hline Geofon & $10 / 06 / 10$ & $06: 38$ & 6.1 & 39.88 & 74.88 & 28 & 5.6 & 5.658 \\
\hline TS & $10 / 06 / 10$ & $06: 38$ & 4.69 & 39.9304 & 74.8708 & 19.9 & & \\
\hline
\end{tabular}

Source parameters from the Preliminary Determinations of Epicenters (PDE) catalog, GEOFON catalog and earthquake locations derived in this study (TS). 
earthquake location derived in this study (Table 5) shows that the epicentral distance ranges from 6 to $34 \mathrm{~km}$, which is interpreted as a significant improvement in earthquake location accuracy.

The 35 fault plane solutions from first motion polarities and the nine moment tensors show a mixture of thrust and strike-slip mechanisms with compressional axes trending NNW-SSE. Especially east of the Fergana Basin, where some rare information about the kinematics of the earthquakes was available, the results of this study contribute to filling this gap. The derived stress ratio of $R=0.19$ and the observed strike-slip mechanisms confirm the existence of shear and thrust components in the regional deformation field, resulting in a transpressional tectonic regime (Cobbold et al. 1996). The combined analysis of all results obtained in this study led to some possible classification of mapped faults as currently active and also revealed some previously unknown tectonic faults like the strike-slip structures in the central and eastern parts of the study area.

From the Pamirs in the south to the Chatkal Range in the north, a rotation of the main stress axes from N-S to NW-SE takes place. This behavior is also observed in the horizontal velocity field derived from GPS measurements (arrows in Figure 3; Zubovich et al. 2010). With our new information about the kinematics of local earthquakes and principal stress axes, we can confirm that the counterclockwise rotation of the Fergana Basin converts the north-south movement of the South Tien Shan into NW-SE shortening across the Chatkal range (Zubovich et al. 2010). The regional stress inversion reveals a maximum principal stress in the direction of $340^{\circ}$ and a minimum principal stress trending $70^{\circ}$.

In this study, a minimum 1D velocity model was derived for the Fergana region. This was the first step toward a 3D velocity model which includes lateral inhomogeneities and therefore describes the velocity structure in a more appropriate way. The results derived in this study also supply the basis for a regional stress inversion, which could improve the actual knowledge about stress in the Fergana region.

\section{Competing interests}

The authors declare that they have no competing interests.

\section{Authors' contributions}

CF carried out the earthquake localization, calculation of fault plane solution and moment tensor inversion. He wrote most of the text. $\mathrm{CH}$ carried out the experiment and calculated the final earthquake locations. BS was involved in the experiment provided the moment tensor inversion code. CS provided the preliminary earthquake database. H-UW and SR provided discussion of the tectonics in the study area. MI carried out the stress tensor inversion. UA and SO participated in the fieldwork and helps with local coordination. All authors discussed the results, shared in writing the manuscript, and read and approved the final manuscript.

\section{Acknowledgements}

We gratefully acknowledge the landowners hosting our stations, the Central Asian Institute for Applied Geosciences (CAIAG), and the Ministry of Emergency
Situations of the Kyrgyz Republic. All field personnel did a great job under difficult conditions, particularly T. Ryberg, T. Ziegenhagen, A. Sharshebaev, A. Dudashvili, and A. Meleshko. This work was realized within the CAME project bundle TIPTIMON, funded by the German Federal Ministry of Education and Research (support code 03G0809). Deutsches GeoForschungsZentrum (GFZ) financed the FERGANA station deployment; the Geophysical Instrument Pool Potsdam (GIPP) provided the instruments. J. Mechie generously provided the preliminary 1D velocity model. Most of the figures were created with the GMT software (Wessel and Smith 1998).

\section{Author details}

${ }^{1}$ Helmholtz-Zentrum Potsdam - Deutsches GeoForschungsZentrum GFZ, Telegrafenberg, 14473 Potsdam, Germany. ${ }^{2}$ Current address: Research School of Earth Sciences, The Australian National University, Canberra, Australia. ${ }^{3}$ Central Asian Institute for Applied Geosciences (CAIAG), Bishkek, Kyrgyzstan.

Received: 2 June 2014 Accepted: 26 January 2015

Published online: 18 March 2015

\section{References}

Bazhenov M (1993) Cretaceous paleomagnetism of the Fergana basin and adjacent ranges, central Asia: tectonic implications. Tectonophysics 221(2):251-267

Burtman V (1975) Structural geology of Variscan Tien Shan, USSR. Am J Sci 275:157-186

Burtman V (1980) Faults of middle Asia. Am J Sci 280(8):725

Burtman V (2000) Cenozoic crustal shortening between the Pamir and Tien Shan and a reconstruction of the Pamir-Tien Shan transition zone for the Cretaceous and Palaeogene. Tectonophysics 319(2):69-92

Buslov M, Klerkx J, Abdrakhmatov K, Delvaux D, Batalev V, Kuchai O, Dehandschutter B, Muraliev A (2003) Recent strike-slip deformation of the northern Tien Shan. Geol Soc Lond Spec Publ 210(1):53-64

Buslov M, De Grave J, Bataleva E, Batalev V (2007) Cenozoic tectonic and geodynamic evolution of the Kyrgyz Tien Shan Mountains: a review of geological, thermochronological and geophysical data. J Asian Earth Sci 29(2-3):205-214

Chedia O (1986) Morphostrukturi i noveishi tektogenes Tian-Shana. Frunse, llim, p 313, In Russian

Cobbold P, Davy P, Gapais D, Rossello E, Sadybakasov E, Thomas J, Tondji Biyo J, De Urreiztieta M (1993) Sedimentary basins and crustal thickening. Sediment Geol 86(1-2):77-89

Cobbold P, Sadybakasov E, Thomas J (1996) Cenozoic transpression and basin development. Kyrghyz Tien Shan, Central Asia, p 181

Ducea M, Lutkov V, Minaev V, Hacker B, Ratschbacher L, Luffi P, Schwab M, Gehrels G, McWilliams M, Vervoort J, Metcalf J (2003) Building the Pamirs: the view from the underside. Geology 31(10):849-852

Dziewonski AM, Chou T-A, Woodhouse JH (1981) Determination of earthquake source parameters from waveform data for studies of global and regional seismicity. J Geophys Res 86:2825-2852, doi:10.1029/JB086iB04p02825

Ekström G, Nettles M, Dziewonski AM (2012) The global CMT project 2004-2010: centroid-moment tensors for 13,017 earthquakes. Phys Earth Planet Inter 200-201:1-9, doi:10.1016/j.pepi.2012.04.002

Ghose S, Hamburger M, Ammon C (1998) Source parameters of moderate sized earthquakes in the Tien Shan, central Asia from regional moment tensor inversion. Geophys Res Lett 25:3181-3184

Haberland C, Maercklin N, Kesten D, Ryberg T, Janssen C, Agnon A, Weber M, Schulze A, Qabbani I, El-Kelani R (2007) Shallow architecture of the Wadi Araba fault (Dead Sea Transform) from high-resolution seismic investigations. Tectonophysics 432(1-4):37-50

Haberland C, Abdybachaev U, Schurr B, Wetzel H, Roessner S, Sarnagoev A, Orunbaev S, Janssen C (2011) Landslides in southern Kyrgyzstan: understanding tectonic controls. Eos Trans AGU 92:20

Judachin F (1983) Geo_sisheskije polja, glubinnoe stroenie i seismichnost Tian-Shana. Frunse, llim, p 247, In Russian

Kalmetieva ZA, Mikolaichuk AV, Moldobekov BD, Meleshko AV, Jantaev MM, Zubovich AV, Havenith HB (2009) Atlas of earthquakes in Kyrgyzstan. CAIAG, Bishkek, 75 pp

Kissling E, Ellsworth WL, Eberhart-Phillips D, Kradolfer U (1994) Initial reference models in local earthquake tomography. J Geophys Res Sol Earth (1978-2012) 99(B10):19635-19646 
Kissling E, Kradolfer U, Maurer H (1995) VELEST user's guide - short introduction. Zurich - Technical Report, Institute of Geophysics and Swiss Seismological Service, ETH

Lee W, Lahr J (1972) HYPO-71 a computer program for determining hypocentre magnitude and first motion pattern of local earthquakes. Open-File Report, US Geol. Surv, 100 pp

Mechie J, Yuan X, Schurr B, Schneider F, Sippl C, Ratschbacher L, Minaev V, Gadoev M, Oiahmadov I, Abdybachaev U, Moldobekov B, Orunbaev S, Negmatullaev S (2012) Crustal and uppermost mantle velocity structure along a profile across the Pamir and southern Tien Shan as derived from project TIPAGE wide-angle seismic data. Geophys J Int 188(2):385-407, ISSN 1365-246X. doi:10.1111/j.1365-246X.2011.05278.x

Michael A (1984) Determination of stress from slip data: faults and folds. J Geophys Res 89(B13):11517-11526

Michael A (1987) Use of focal mechanisms to determine stress: a control study. J Geophys Res 92(B1):357-368

Mikhailova NN, Sinyova Zl (2010) New ground truth events in Central Asia. Technical report, Institute of Geophysical Research, Almaty

Molnar P, Tapponnier P (1975) Cenozoic tectonics of Asia: effects of a continental collision. Science 189(4201):419-426

Molnar P, Fitch T, Wu F (1973) Fault plane solutions of shallow earthquakes and contemporary tectonics in Asia. Earth Planet Sci Lett 19(2):101-112

Nabelek J, Xia G (1995) Moment-tensor analysis using regional data: application to the 25 March, 1993, Scotts Mills, Oregon, Earthquake. Geophys Res Lett 22(1):13-16

Nelson M, McCaffrey R, Molnar P (1987) Source parameters for 11 earthquakes in the Tien Shan, central Asia, determined by $\mathrm{P}$ and $\mathrm{SH}$ waveform inversion. J Geophys Res 92(B12):12629-12648

Ni J (1978) Contemporary tectonics in the Tien Shan region. Earth Planet Sci Lett 41(3):347-354

Osmonbetov KO, Shukov JV, Samaletdinov TS, Israeleva RM (1989) Tectonical maps, scale 1: 500 000, sheets K-43A, K-43-C, K-J-43-A. Goskartografia, Bishkek, In Russian

Reasenberg P, Oppenheimer D (1985) FPFIT, FPPLOT, and FPPAGE: Fortran computer programs for calculating and displaying earthquake fault-plane solutions. US Geological Survey Open-File Report 85-739

Roessner S, Wetzel HU, Kaufmann H, Sarnagoev A (2005) Potential of satellite remote sensing and GIS for landslide hazard assessment in Southern Kyrgyzstan (Central Asia). Nat Hazards 35:395-416

Schurr B, Nabelek J (1999) New techniques for the analysis of earthquake sources from local array data with an application to the 1993 Scotts Mills, Oregon, aftershock sequence. Geophys J Int 137(3):585-600

Schurr B, Ratschbacher L, Sippl C, Gloaguen R, Yuan X, Mechie J (2014) Seismotectonics of the Pamir. Tectonics 33(8):1501-1518

Simpson D, Hamburger M, Pavlov V, Nersesov I (1981) Tectonics and seismicity of the Toktogul reservoir region, Kirgizia, USSR. J Geophys Res 86(B1):345-358

Simpson D, Richards P, Lerner-Lam A (1987) Regional network: seismicity of Asia and frequency-dependent Q, technical report. Air Force Geophysics Laboratory, New York

Sippl C, Schurr B, Yuan X, Mechie J, Schneider FM, Gadoev M, Orunbaev S, Oimahmadov I, Haberland C, Abdybachaev U, Minaev V, Negmatullaev S, Radjabov N (2013) Geometry of the Pamir-Hindu Kush intermediate-depth earthquake zone from local seismic data. J Geophys Res Solid Earth 118:1438-1457, doi:10.1002/jgrb.50128

Styron R, Taylor M, Okoronkwo K (2010) HimaTibetMap-1.0: new 'web-2.0' online database of active structures from the Indo-Asian collision. Eos 91:20

Taylor M, Yin A (2009) Active structures of the Himalayan-Tibetan orogen and their relationships to earthquake distribution, contemporary strain field, and Cenozoic volcanism. Geosphere 5(3):199-214

Thomas J, Perroud H, Cobbold P, Bazhenov M, Burtman V, Chauvin A, Sadybakasov E (1993) A paleomagnetic study of Tertiary formations from the Kyrgyz Tien-Shan and its tectonic implications. J Geophys Res 98(B6):9571-9589

Wessel P, Smith WH (1998) New, improved version of Generic Mapping Tools released. Eos, Transactions American Geophysical Union 79(47):579

Windley B, Allen M, Zhang C, Zhao Z, Wang G (1990) Paleozoic accretion and Cenozoic redeformation of the Chinese Tien Shan range, central Asia. Geology 18(2):128
Xu Y, Roecker S, Wei R, Zhang W, Wei B (2006) Analysis of seismic activity in the crust from earthquake relocation in the central Tien Shan. Bull Seismol Soc Am 96(2):737

Yin A, Nie S, Craig P, Harrison T, Ryerson F, Xianglin Q, Geng Y (1998) Late Cenozoic tectonic evolution of the southern Chinese Tian Shan. Tectonics 17(1):1-27

Zubovich A, Wang X, Scherba Y, Schelochkov G, Reilinger R, Reigber C, Mosienko O, Molnar P, Michajljow W, Makarov V, Li J, Kuzikov S, Herring T, Hamburger M, Hager B, Dang Y, Bragin V, Beisenbaev R (2010) GPS velocity field for the Tien Shan and surrounding regions. Tectonics 29(6), TC6014

\section{Submit your manuscript to a SpringerOpen ${ }^{\odot}$ journal and benefit from:}

- Convenient online submission

- Rigorous peer review

- Immediate publication on acceptance

- Open access: articles freely available online

- High visibility within the field

- Retaining the copyright to your article

Submit your next manuscript at $>$ springeropen.com 